\title{
Total Quality Management - A Recommended Strategy For The Pakistani Banking Sector
}

\author{
Hummayoun Naeem, Foundation University Institute of Management \& Computer Sciences, Pakistan \\ M. Iqbal Saif, Foundation University Institute of Management \& Computer Sciences, Pakistan \\ Salman Qasim, Foundation University Institute of Management \& Computer Sciences, Pakistan
}

\begin{abstract}
Keeping in view the significance of TQM in today's competitive banking environment, the study was designed to look into the quality implementation level of commercial banks in Pakistan. Main offices of all commercial banks operating in Pakistan were contacted and were asked about the level of implementation of TQM in their bank; whether the quality implementation is at its introductory, middle, final or fully implemented stage. The data indicated that majority of the banks in Pakistan are at the introductory stage where as almost one fifth claim having TQM fully implemented. The situation highlights the level of effort put by management of banks operating in Pakistan and initiatives taken by them in respect of quality management. The findings of the study may be passed on to Central Bank for further necessary action and follow up.
\end{abstract}

Keywords: Total Quality Management, Level of Implementation, Commercial Banks in Pakistan

\section{INTRODUCTION}

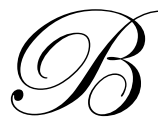

anks play their significant role in any economic system. They are financial intermediaries involve in transfers of funds within and outside the country. Banking sector is getting competitive every day. Quality, speed, efficiency, innovation are the main points on which quality programs are designed. All banks are engaged in same basic banking activities but it is the way of delivery of service that distinguishes one bank form the other. All banks world wide are considering quality in the strategic management. In Pakistan too, banks have started paying attention to quality aspects of their business. Foreign banks are quite ahead in this race. The researcher plans to carry out this study to collect data systematically and to see the status of quality implementation in different banks operating in Pakistan.

\section{STATEMENT OF THE PROBLEM}

Banking sector is getting competitive every day. In order to be successful in the field, TQM ought to be the integral part of their strategic management. The research is designed to investigate the level of implementation of TQM in various commercial banks operating in Pakistan. The researcher also plans to design a quality model applicable to all commercial banks.

\section{OBJECTIVES OF THE STUDY}

1. To study TQM implementation level in different commercial banks in Pakistan.

2. To develop and propose a quality model for banking services 


\section{METHODOLOGY}

In order to study the level of TQM implementation, the researcher developed an interview guide and interviewed senior managers of different commercial banks in Pakistan. Data collected was presented in a table indicating the bank name and level of TQM implementation i.e. introduction level, medium level and fully implemented.

The quality model developed by the researcher is based upon extensive literature review carried out for the present study.

\section{LITERATURE REVIEW}

\begin{tabular}{|c|c|c|c|}
\hline \multicolumn{2}{|c|}{ Year } & \multirow{2}{*}{$\begin{array}{c}\text { Author } \\
\text { Newman and } \\
\text { Cowling }\end{array}$} & Findings \& Conclusion \\
\hline 01 & 1995 & & $\begin{array}{l}\text { Introduction of TQM in two major banks of UK. Employee success depends upon } \\
\text { employee empowerment Senior management and HR dept need to be involved. Increased } \\
\text { competition and higher customer expectations are the main factors behind the adoption of } \\
\text { quality programs in Financial Services. }\end{array}$ \\
\hline 02 & 1998 & Sim and Killough & $\begin{array}{l}\text { concluded that TQM had a positive effect on customers and quality of employee } \\
\text { performance. Ittner and Larcker (1995) highlited the problem solving nature of TQM } \\
\text { environment. Chenhall (2003) found that TQM application resulted into the following: } \\
\text { "flexible systems, focused information; close interactions between advanced technologies } \\
\text { and strategy and non-financial performance measurement". }\end{array}$ \\
\hline 03 & 1999 & Burton and Philip & $\begin{array}{l}\text { The role of leadership in TQM implementation was further explored by Burton and Philip } \\
\text { (1999) while concluding that a "strong leadership commitment" and "a long term cultural } \\
\text { change" were necessary for the implementation of TQM in any organization. The study } \\
\text { further highlighted the role of effective leadership and strategic quality planning while } \\
\text { empowering employees and concentrating on their training in different dimensions of } \\
\text { TQM. }\end{array}$ \\
\hline 04 & 1999 & $\begin{array}{l}\text { Saffran, Norbert; } \\
\text { Vogt, Ulrike; }\end{array}$ & $\begin{array}{l}\text { Deutsche Bank A G has introduced a quality management system based on ISO } 9000 \text { in } \\
\text { banks payment transactions system. Success of Deutsche Bank quality system was based } \\
\text { on adopting the system to new requirements like employee involvement, open } \\
\text { communication, customer orientation and flexibility. }\end{array}$ \\
\hline 05 & 2006 & $\begin{array}{l}\text { Z. Rahman, } \\
\text { J. Siddiqui }\end{array}$ & $\begin{array}{l}\text { A survey was conducted amongst the business areas belong to different classes such as } \\
\text { insurance, banking, software, manufacturers etc of } 300 \text { Indian companies to know the use } \\
\text { of TQM in there is departments. The most important factor is top management support on } \\
\text { which TQM implementation benefits rely. }\end{array}$ \\
\hline 06 & 2006 & Samat \& Saad & $\begin{array}{l}\text { Implementing TQM tenets like employee empowerment, effective communication, } \\
\text { customer entered strategies and continuous improvement always resulted into high level } \\
\text { of service quality. }\end{array}$ \\
\hline 07 & 2007 & $\begin{array}{l}\text { Arturo Molina, } \\
\text { David Martin- } \\
\text { Consuegra, } \\
\text { Agueda Esteban }\end{array}$ & $\begin{array}{l}\text { From a sample of } 204 \text { bank customers a study was conducted regarding the relationship } \\
\text { between relational benefits and customer satisfaction. So from the set of social benefits, } \\
\text { special treatment benefits and confidence benefits, the confidence benefits have a positive } \\
\text { effect on customer satisfaction with their banks. }\end{array}$ \\
\hline 08 & 2007 & Fadzian Sufian & $\begin{array}{l}\text { From the three different types of efficiency namely technical, pure technical and scale } \\
\text { efficiencies DEA examines its relationship with the traditional measure of bank's } \\
\text { performance. The result stated that the banking groups efficiency in earlier part was on } \\
\text { declining trend whereas in later period it was dramatically increasing. }\end{array}$ \\
\hline 09 & 2007 & $\begin{array}{l}\text { Jamshed siddiqui, } \\
\text { Zill-ur-Rahman. }\end{array}$ & $\begin{array}{l}\text { By conducting a questionnaire survey of managers, multivariate analysis of qualitative } \\
\text { responses state that TQM philosophy is based on top management commitment, } \\
\text { benchmarking for problem solving etc. TQM and IS can be fruitful in improving the } \\
\text { quality of products and services offered to the end customers. }\end{array}$ \\
\hline 10 & 2007 & $\begin{array}{c}\text { Khalid Al-Marri } \\
\text { and others. }\end{array}$ & $\begin{array}{l}\text { Data collected from } 250 \text { banks in UAE to examine the critical success factor of TQM } \\
\text { implementation in UAE banking sector. The ratios of critical TQM implementations } \\
\text { success were } 16 \text { in numbers. Some are top management support, strategy, recognition and } \\
\text { reward etc. }\end{array}$ \\
\hline
\end{tabular}


Above studies indicate that:

- $\quad$ Due to increased competition, TQM implementation is inevitable

- $\quad$ success of TQM program in financial sector is associated with strong leadership emphasizing strategic and tactical planning.

- the top-down training programs need to be started in order to attain desired quality level in banking industry.

- $\quad \mathrm{TQM}$ is a long term cultural commitment requiring a strong leadership commitment

- $\quad$ Top management support is a key factor in quality implementation

- $\quad$ Implementing TQM results into higher level of service quality

In order to achieve higher level of service quality in Pakistani Banking sector, it is need of the hour to pay full attention to strategic quality planning.

Table 1 - Status of Quality implementation of Various Banks Operating in Pakistan

\begin{tabular}{|c|c|c|c|}
\hline Name of the Bank & TQM as a Strategy & Since & $\begin{array}{c}\text { Level of } \\
\text { Implementation }\end{array}$ \\
\hline State Bank of Pakistan & Yes & 2006 & Introductory \\
\hline First Women Bank Limited & Yes & 2005 & Introductory \\
\hline National Bank of Pakistan & Yes & 2006 & Introductory \\
\hline Allied Bank of Pakistan Ltd. & Yes & 2005 & Middle \\
\hline Askari Commercial Bank Ltd. & Yes & 2004 & Middle \\
\hline Bank Al-Habib & Yes & N/A & N/A \\
\hline Faysal Bank Ltd. & Yes & 2003 & Middle \\
\hline Habib Bank Ltd. & Yes & 2007 & Introductory \\
\hline KASB Bank Ltd. & Yes & 2006 & Introductory \\
\hline Meezan Bank Ltd. & Yes & 2005 & Introductory \\
\hline MCB Limited & Yes & 2005 & Middle \\
\hline My Bank Ltd. & Yes & 2006 & Middle \\
\hline NIB Bank Ltd. & Yes & 2006 & Introductory \\
\hline PICIC Commercial Bank Ltd & Yes & 2005 & Middle \\
\hline United Bank Ltd. (UBL) & Yes & 2005 & Middle \\
\hline Khushali Bank & No & - & - \\
\hline SME Bank & No & - & - \\
\hline Zarai Taraqiati Bank & No & - & - \\
\hline Habib Metropolitan Bank Ltd. & Yes & 2006 & Introductory \\
\hline Standard Chartered Bank Ltd. & Yes & 2001 & Top \\
\hline Abn Amro Bank NV & Yes & N/A & Top \\
\hline Citi Bank NV & Yes & 2001 & Top \\
\hline Dubai Islamic Bank & Yes & 2003 & Middle \\
\hline Bank Alfalah & Yes & 2003 & Top \\
\hline UBL Ameen Islamic Bank & Yes & 2006 & Introductory \\
\hline Albaraka Islamic Bank BSC(EC) & Yes & N/A & N/A \\
\hline First Dawood Islamic Bank & Yes & 2007 & Middle \\
\hline Crescent Investment Bank Ltd & Yes & 2005 & Introductory \\
\hline
\end{tabular}

The data indicated that majority of the banks in Pakistan are at the introductory stage where as almost one fifth claim having TQM fully implemented. The situation highlights the level of effort put by management of banks operating in Pakistan and initiatives taken by them in respect of quality management.

In this scenario when the TQM implementation is very very low in Pakistan, the researcher presents a TQM model for Commercial Branch Banking Operations (figure 1) covering all aspects of branch banking. 


\section{TQM Model of Commercial Branch Banking Operations}

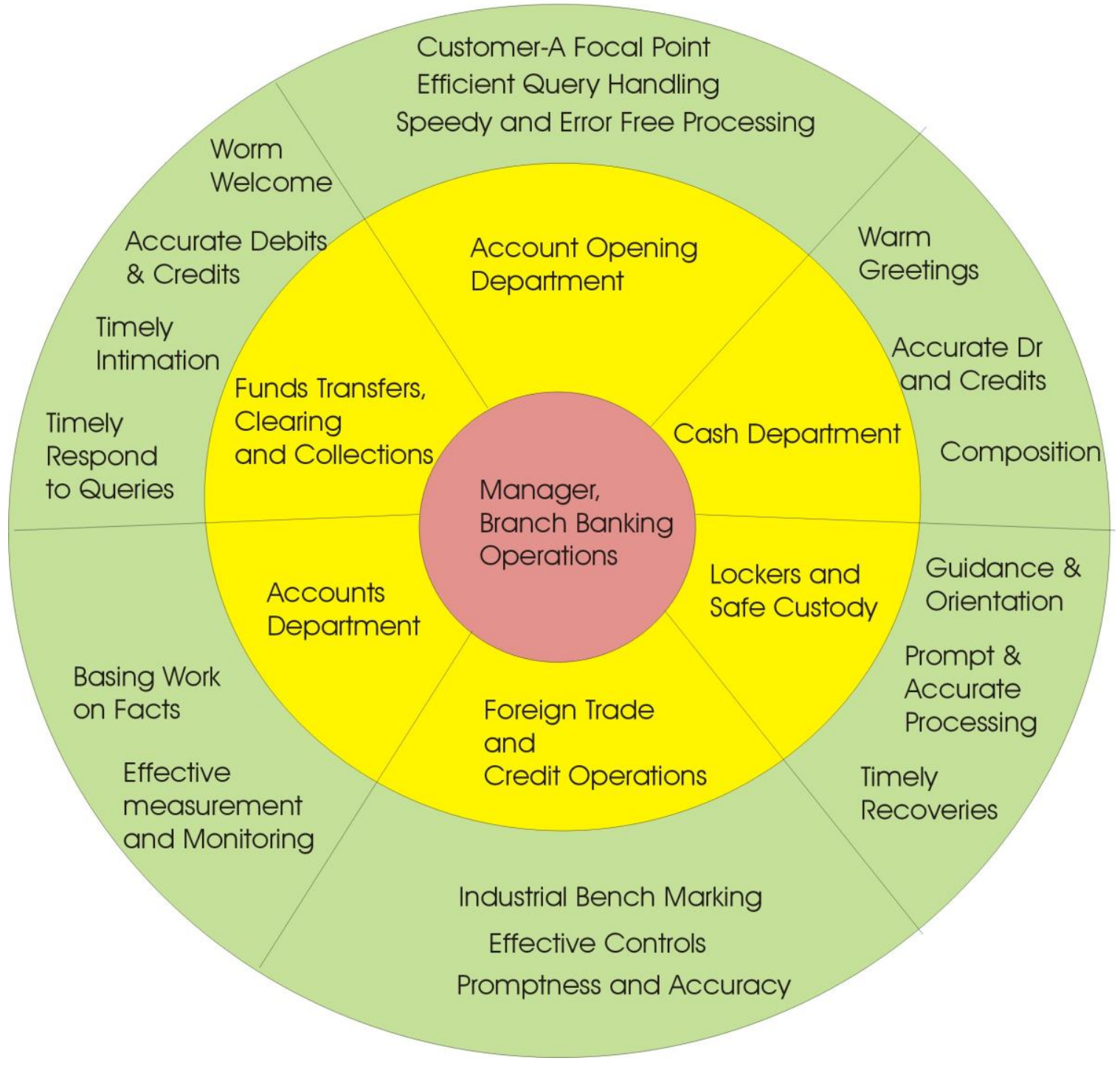

Figure 1

Figure 1 - Source:

Ngware, Moses W. et al. (2006) "Total Quality Management in secondary schools in Kenya" Quality Assurance in Education. Volume 14 Number 4, pp.339-362 and;

Zeithaml, V.A., Parasuraman, A. and Berry.(1990) "Delivering Quality Service; Balancing Customer Perceptions and Expectations," Free Press and

Researcher's own processing 


\section{Diagnostic Nature Of The Proposed Model}

The proposed model is diagnostic in nature and has the capacity to diagnose problems in the following areas:

- While taking the model as operationalization of TQM in banking, the level of implementation may be checked with an appropriate scale.

- $\quad$ The model may be taken as an independent variable. Strict adherence to TQM principles may lead towards higher customer satisfaction (dependent variable) \& financial performance (dependent variable).

\section{ELABORATION OF THE MODEL}

\section{The Effective Role Of Leader}

Branch Manager is the leader, responsible for the smooth running of day to operations and also for the business growth at branch level. He should present himself as a dedicated and committed role model to be followed by other staff members. He should be able to motivate staff for quality services

\section{Account Opening Department}

The Officer Incharge of Account Opening Department is responsible of opening new accounts and activating the dormant ones. He should be able to serve the customers promptly, should make the account opening process the pleasant experience

\section{Accounts Department}

The Officer Incharge of Accounts Department is responsible for book keeping (profit / loss accounts, accruals, depreciations etc.) of the branch transactions and also for budgetary aspects. He should be able to base his work on facts which means having more realistic approach towards branch activity and business growth.

\section{Remittances (Inwards And Outward), Clearing And Collections (Inward And Outward)}

The Officer Incharge of Remittances Department is responsible for processing customers requests for funds transfer. He should be able to maintain efficient documentation. Should concentrate on speedy and error free processing.

\section{Cash Department}

The Officer Incharge of Cash Department is responsible for cash receipts and payments. He should be able to serve customers with smiling face and due courtesy, should process cash receipts and withdrawals accurately and efficiently, makes additional arrangements on cash tills in case of long queue.

\section{Term Deposits - Issuance \& Encashment}

The Officer Incharge of Term Deposits is responsible for the issuance and encashment of Term Deposits. He should be able to process the applications timely, exercise due vigilance while disbursing profit on deposits, works on the processes and procedures to lessen the time required for the issuance and encashment of term certificates.

\section{CONCLUSION}

In this competitive age, the survival of a business mainly depends upon the quality associated with the product. Similarly, in order to succeed in commercial banking, there is a need to develop an organizational culture 
based on Quality Management approach where every body is involved in quality enhancement processes and the bank management is keen and fully committed to the satisfaction of both internal and external customers.

\section{REFERENCES}

1. Burton, Gummer et al. (1999) TQM and Organizational Change and Development Rockfield College Press, Albany, New York.

2. $\quad$ Cole, William E. \& John W. Mogab. 1999. TQM in Action. Beacon Books, New Delhi.

3. http://qic.asq.org/perl/search.pl?item=10793 Retrieved on April 13, 2007

4. Janakiraman, B., and R. K. Gopal (2006) Total Quality Management: Text and Cases. Prentice Hall of India Pvt. Ltd. New Delhi.

5. Newman, Karim \& Alan Cowling (1996) Service Quality in Retail Banking. International Journal of Bank Marketing. Vol 14, Issue 6

6. Ngware, Moses W. et al. (2006) Total Quality Management in secondary schools in Kenya Quality Assurance in Education. Volume 14 Number 4, pp.339-362

7. Pearce John A. and Richard B. Robinsons. 2005. Strategic Management. McGraw Hill, New York

8. Rana, Imran Ahmed. 2005. TQM Paradigm in Banking. www.dawn.com

9. Saffran, Norbet and Ulrike Vogt. (1999) Case study; ISO 9000; Implementation; Quality system; Total Quality Management at Deutsche Bank AG; Management Systems, Inc., Wilmette, IL. Annual Quality Congress, Anaheim, CA, Vol. 53, MAY 1999

10. Sim, K.L. and L. N. Killough. (1998)The Performance Effects of Complementaries Between Manufacturing Practices and Management Accounting Systems. Journal of Management Accounting Research 10, pp. 325-346

11. Zeithaml, V.A., Parasuraman, A. and Berry.(1990) Delivering Quality Service; Balancing Customer Perceptions and Expectations, Free Press 